\title{
Anti-Haemorrhagic Activity of Polyherbal Formulation in Menorrhagia: A Randomized Controlled Trial
}

\author{
Danish Jahan $^{1^{*}}$, Wajeeha Begum ${ }^{2}$, Mariyam Roqaiya ${ }^{2}$, Yousuf Khalil Hussaini ${ }^{3}$ \\ ${ }^{1}$ National Institute of Unani Medicine, Kottigepalya, Bengaluru, Karnataka, India \\ ${ }^{2}$ Luqman Unani Medical College, Hospital \& Research Centre, 12 Naubag, Bijapur, Karnataka, India \\ 3 Jamia Tibbiya Deoband, Uttar Pradesh, India.
}

*Correspondant author: Danish Jahan, National Institute of Unani Medicine, Kottigepalya, Bengaluru, Karnataka, India, Tel: +91 9535181736, E-mail: dr.danishjahan@gmail.com

Received date: June 11, 2016; Accepted date: July 15, 2016; Published date: July 22, 2016

Copyright: @2016 Jahan D. This is an open-access article distributed under the terms of the Creative Commons Attribution License, which permits unrestricted use, distribution, and reproduction in any medium, provided the original author and source are credited.

\section{Abstract}

Background: Menorrhagia i.e., excessive menstrual blood loss is a common problem that interferes with women's physical, emotional, social and material quality of life. Unani physicians have mentioned so many herbal formulations to treat menorrhagia. This study was aimed to compare the efficacy of polyherbal unani formulation and tranexamic acid on menorrhagia.

Materials \& Methods: This prospective randomized single blind standard controlled trial was conducted in Department of Niswan wa Qabala, National Institute of Unani Medicine. 40 patients were assigned to test (20) and control (20) groups. Both the test as well as control was given orally for five days from first day of menstrual cycle for two consecutive cycles. Assessment of efficacy was based on pictorial blood loss assessment chart (PBAC) to assess the amount of blood loss. $\mathrm{Hb} \%$ and quality of life were also assessed as secondary outcome. Chi-square/ Fisher Exact test has been used to find the significance of study parameters on categorical scale between groups.

Results: There was no significant difference found between the groups on all parameters assessed which shows that the test drug can be an alternative for tranexamic acid after clinical trial on large sample size and for longer duration.

Conclusion: Test drug has been found having equal effect with tranexamic acid. There is need for further study on large sample size.

Keywords: Menorrhagia; Polyherbal; Anti-haemorrhagic

\section{Introduction}

Heavy flow during periods is called menorrhagia or kasrate tams and it is one of the most common reasons for women to be referred to gynecologists. It is the main presenting problem in at least half of those who undergo hysterectomies [1]. Prevalence of menorrhagia is approximately $10 \%$ to $15 \%$ in women of reproductive age [2]. It has two conditions, either flow increases in amount or duration $[3,4]$.

Indeed, the associated discomfort, anxiety and impaired quality of life lead many women to surgical procedures, ranging from endometrial ablation to hysterectomy, often in the absence of any detectable pathology [5]. Several drug classes are recommended for the treatment of heavy menstrual bleeding (HMB); however, most of them are not accepted by patients because of either failure in controlling the bleeding or side-effects [6].

Unani physicians have stated that in kasrate tams excessive flow of blood is mainly due to two causes that is weakness in quwate masika (retentive power) or increase in quwate dafiya (excretory power) or both. Cause of weakness of quwate dafiya is any type of sue mizaj (abnormal temperament), mainly sue mizaj haar yabis (hot \& dry), which causes weakness of uterus and its vessels and leads to opening of mouth of vessels and rupture of vessels.

Cause of excess functioning of quwate dafiya (excretory power) is due to khilt lazaa, hararat and hiddat (excess heat) of blood. This hiddat and lazaa again causes opening of mouth of blood vessels $[7,8]$.

In unani literature numbers of drugs are available single as well as in compound form to treat haemorrhage. Almost same drugs have also been mentioned for menorrhagia. These drugs are effective to control bleeding by having its haemostatic and astringent property e.g., anjabar, geru, sange jarahat, dammul akhwain, etc. $[9,10]$. A polyherbal unani formulation sharbate anjbar is the most popular and most common composition to treat haemorrhage [11-13].

Sharbate anjbar is available with different formulations which are being used from many years for haemorrhage. So considering the above fact, the present study was carried out in Dept. of Ilmul Qabalat wa Amraze Niswan, NIUM Hospital, Bangalore, to scientifically evaluate the efficacy of sharbate anjbar in the management of menorrhagia.

Sharbate anjbar is having four drugs beekhe anjabr (Polygonum bistorata), aqaqia (Acacia arabica), sandal surkh, sandal sufaid (Santalum album) [12,13]. These drugs have habis (hemostatic) and qabiz (astringent) properties. 
Page 2 of 4

\section{Materials and Methods}

A prospective single blind randomized standard controlled study was conducted in the Dept. of Ilmul Qabalat wa Amraze Niswan, NIUM Hospital, Bangaluru from November 2014 to March 2015 to compare the efficacy of polyherbal unani formulation and tranexamic acid on menorrhagia. The study protocol was approved by Institutional Ethical Committee, NIUM Bangalore.

Inclusion criteria were married as well as unmarried women of reproductive age group complaining of heavy menses with regular cycles. Patients with irregular and inter-menstrual bleeding, patient suffering from systemic illness, blood dyscrasias, malignancy and severe anaemia ( $\mathrm{Hb} \%$ less than $7.5 \mathrm{~g}$ ), unwillingness or inability to comply the requirements of the protocol were excluded from the study.

In each patient, history was evaluated and a complete physical examination including breast and abdominal examination and per vaginal (in married patients) examination was performed. Personal details, history, clinical features and investigations were recorded in the case record form (CRF) structured for the study.

Following thorough evaluation of patient by history and clinical examination, patients were advised for necessary investigations. Complete blood picture with ESR, BT, CT, Platelet count, Random blood sugar, Complete urine examination, Blood urea, serum creatinine, SGOT, SGPT, alkaline phosphatise, Whole abdomen scan Thyroid profile, Pap smear (in married patients) were investigated.

After a control cycle, (Figure 1) total of 40 patients meeting the inclusion criteria were randomly assigned to test (20 patients) and control (20 patients) groups after explaining the study in detail and receiving the informed consent. Randomization was done by using computer generated random table.

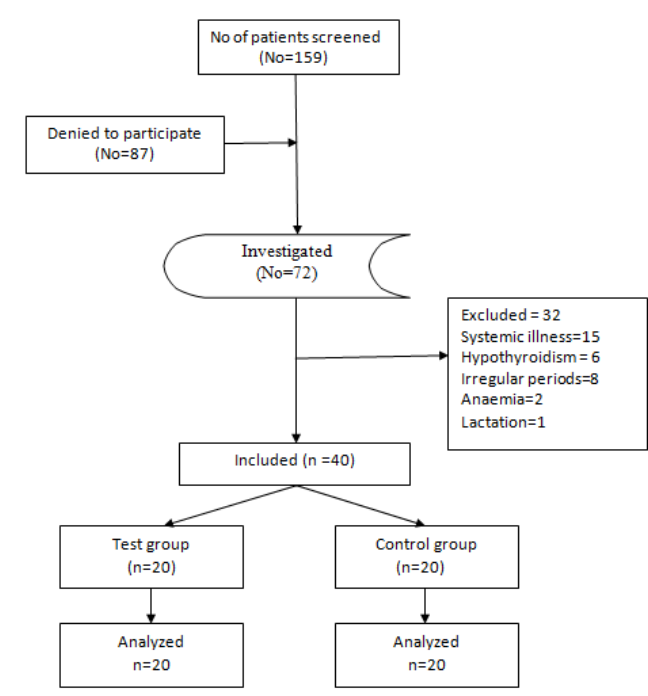

Figure 1: Flow diagram of the participants.

For the test group a polyherbal syrup formulation sharbate anjbar was selected which contains beekhe anjbar, aqaqia, sandal surkh, and sandal sufaid. These drugs were purchased from local drug retailer of Bangalore by purchase committee and were identified by Dept. of Pharmacology, NIUM.
Syrup was prepared in pharmacy of this institute according to the standard unani method of preparation and given in the dose of $25 \mathrm{ml}$ BD for 5 days during menses from the first day of menstrual cycle for two consecutive cycles. In the control group standard drug tranexamic acid $500 \mathrm{mg}$ BD was also given for 5 days from the first day of menstrual cycle for two cycles. Assessment of blood loss during periods was done by PBAC score and assessment in improvement of quality of life was done by SF-36 score.

Patients were assessed for two consecutive cycles during the treatment and one cycle after the treatment. During treatment amount of bleeding were assessed by asking duration of cycle, amount of flow which was assessed by calculating the total no. of pads used in one cycle and duration of flow from both the groups.

Apart from that improvement in quality of life was assessed by using SF-36 questionnaire before and after treatment. Effectiveness of trial drugs were assessed by Pictorial blood loss assessment chart (PBAC score) to assess the amount of blood loss, SF-36 score to asses quality of life and improvement in $\mathrm{Hb} \%$.

Chi-square/Fisher Exact test has been used to find the significance of study parameters on categorical scale between groups.

\section{Results and Discussion}

Baseline demographic profile was same between the two groups with $\mathrm{p}$ value $>0.05$ (Table 1). As shown in Table 2, baseline PBAC score in test group was $496.55 \pm 256.37$ and in control score was 595.70 \pm 379.76 which is not significant between the groups with $p$ value of 0.339 . During first treatment cycle score was calculated as $160.30 \pm$ 54.20 in test group and $257.25 \pm 257.77$ in control group with $p$ value of 0.108 . During second cycle $124.65 \pm 46.57$ score was calculated in test group and $220.95 \pm 246.06$ in control group which is statistically significant between the groups with $\mathrm{p}$ value of 0.094 . During after treatment follow up cycle the score was calculated as $109.50 \pm 38.50$ in test group and $291.85 \pm 483.95$ in control group which is not significant with $\mathrm{p}$ value 0.101 . Mean difference in groups were found 387.05 in test group and 303.85 in control group.

\begin{tabular}{|l|l|l|l|l|l|}
\hline \multirow{2}{*}{ Characteristic } & \multicolumn{2}{l}{ Test group } & \multicolumn{2}{l}{ Control group } & \multirow{2}{*}{ P value } \\
\cline { 2 - 6 } & No & $\%$ & No & $\%$ & \\
\hline Age (years) & & & & & \\
\hline Nov-20 & 5 & 25 & 3 & 15 & \\
\hline $21-30$ & 9 & 45 & 8 & 40 & \\
\hline $31-40$ & 4 & 20 & 7 & 35 & $\mathrm{P}=0.787$ \\
\hline $41-50$ & 2 & 10 & 2 & 10 & \\
\hline Total & 20 & 100 & 20 & 100 & \\
\hline Marital status & & & & & \\
\hline Married & 11 & 55 & 14 & 70 & \\
\hline Unmarried & 9 & 45 & 6 & 30 & $\mathrm{P}=0.327$ \\
\hline Total & 20 & 100 & 20 & 100 & \\
\hline Occupation & & 5 & 1 & 5 & \\
\hline Employed & 1 & & & & \\
\hline
\end{tabular}


Page 3 of 4

\begin{tabular}{|l|l|l|l|l|l|}
\hline House wife & 10 & 50 & 16 & 80 & \\
\hline Student & 9 & 45 & 3 & 15 & $\mathrm{P}=0.100$ \\
\hline Total & 20 & 100 & 20 & 100 & \\
\hline SES & & & & & \\
\hline Lower & 0 & 0 & 1 & 5 & \\
\hline Lower middle & 9 & 45 & 5 & 25 & \\
\hline Upper lower & 5 & 25 & 8 & 40 & $\mathrm{P}=0.699$ \\
\hline Upper middle & 5 & 25 & 5 & 25 & \\
\hline Upper & 1 & 5 & 1 & 5 & \\
\hline Total & 20 & 100 & 20 & 100 & \\
\hline Habitat & & & & & \\
\hline Rural & 1 & 5 & 2 & 10 & \\
\hline Urban & 19 & 95 & 18 & 90 & $\mathrm{P}=1.000$ \\
\hline Total & 20 & 100 & 20 & 100 & \\
\hline Diet & 20 & 100 & 20 & 100 & \\
\hline Mixed & 17 & 85 & 18 & 90 & \\
\hline Veg. & 3 & 15 & 2 & 10 & $\mathrm{P}=0.633$ \\
\hline Total & & & & \\
\hline
\end{tabular}

Table 1: Baseline demographic of the patients with menorrhagia in test and control group.

\begin{tabular}{|c|c|c|c|}
\hline PBAC Score & Test group & Control group & $P$ value \\
\hline Baseline & $496.55 \pm 256.37$ & $595.70 \pm 379.76$ & 0.339 \\
\hline First cycle & $160.30 \pm 54.20$ & $257.25 \pm 257.77$ & 0.108 \\
\hline Second cycle & $124.65 \pm 46.57$ & $220.95 \pm 246.06$ & $0.094+$ \\
\hline $\begin{array}{l}\text { After treatment } \\
\text { follow up }\end{array}$ & $109.50 \pm 38.50$ & $291.85 \pm 483.95$ & 0.101 \\
\hline Difference & 387.05 & 303.85 & - \\
\hline $\begin{array}{l}P \text { value (Before - } \\
\text { After) }\end{array}$ & $<0.001^{* *}$ & $<0.001^{* *}$ & - \\
\hline
\end{tabular}

Table 2: PBAC Score of patients studied.

In present study it is obvious that the test drug has almost equal effect with control drug in improvement of PBAC score. PBAC score to assess the menstrual blood loss has been used in various previous studies conducted. Jaisamrarn et al. [14] has showed a significant decrease in PBAC score from 350.5 to 178.6 with $49 \%$ decrease in mean menstrual blood flow after two cycles which was significant. One more study conducted by Lee et al. [15] showed significant reduction in PBAC score from 262.0 to 125.0 with $47.4 \%$ decrease in mean menstrual blood flow.

Significant improvement in PBAC score in test group is attributed due to haemostatic property of sharbate anjbar by which it reduces bleeding [11-13]. Ingredients of sharbate anjbar contains tannin, gallic

acid, ellagic acid and flavonoids which are potential styptic and astringent there by reduces heavy menstrual blood loss [7,10,16-19]. Acacia arbica one of the ingredients has also been studied for its coagulation property in the mice [20]. Another study has shown that Acacia arabica along with Moringa oleifera are haemostatic and hasten blood coagulation [21].

\begin{tabular}{|l|l|l|l|}
\hline SF-36 Score & Test group & Control group & P value \\
\hline Before treatment & $233.75 \pm 90.42$ & $185.55 \pm 61.06$ & $0.055+$ \\
\hline After treatment & $777.70 \pm 35.65$ & $697.15 \pm 161.89$ & $0.036^{*}$ \\
\hline Difference & 543.95 & 511.6 & - \\
\hline $\begin{array}{l}\text { P value (Before }- \\
\text { After) }\end{array}$ & $<0.001^{* *}$ & $<0.001^{* *}$ & - \\
\hline
\end{tabular}

Table 3: SF-36 Score of patients studied.

Table 3 shows mean SF-36 score. Before treatment it is $233.75 \pm$ 90.42 in test group and $185.55 \pm 61.06$ in control group with a p value of 0.055 and after treatment it is calculated as $777.70 \pm 35.65$ in test group and $697.15 \pm 161.89$ in control group with $p$ value of 0.036 . Mean difference is 543.95 in test group and 511.60 in control group. On inter group comparison before treatment findings were suggestive significant ( $p$ value: $0.05<p<0.10$ ) in both the groups. After treatment findings were moderately significant with $p$ value of ( $p$ value: $0.01<p \leq$ 0.05 ). In test group drug was found more effective in improving quality of life than control group.

Menorrhagia is a common gynecological condition that has a significant impact on the wellbeing and quality of life of many women's. In present study SF-36 questionnaire was used to evaluate the impact of treatment on women's quality of life and it is obvious that test drug is significant in improving women's quality of life. These findings are similar with the studies conducted by Pattison et al. [22] and Marjoribanks et al. [23]. In these studies, significant improvement in quality of life was observed after treatment.

\begin{tabular}{|l|l|l|l|}
\hline SF-36 Score & Test group & Control group & P value \\
\hline Before treatment & $233.75 \pm 90.42$ & $185.55 \pm 61.06$ & $0.055+$ \\
\hline After treatment & $777.70 \pm 35.65$ & $697.15 \pm 161.89$ & $0.036^{*}$ \\
\hline Difference & 543.95 & 511.60 & - \\
\hline P value (Before -After) & $<0.001^{* *}$ & $<0.001^{* *}$ & - \\
\hline
\end{tabular}

Table 4: Hemoglobin \% of patients studied.

Table 4 is showing improvement in $\mathrm{Hb} \%$ in mean \pm SD. Baseline $\mathrm{Hb}$ $\%$ was found $11.71 \pm 1.45$ in test group and $11.66 \pm 1.54$ in control group with $\mathrm{p}$ value of 0.908 and after two treatment cycles it was found $11.96 \pm 1.43$ in test group and $11.56 \pm 1.68$ in control group with $p$ value of 0.428 . On intergroup comparison after treatment findings were not significant $(p>0.05)$. On intra group comparison findings were also not significant $(\mathrm{p}>0.05)$ but in test group drug was found more effective in improving $\mathrm{Hb} \%$ than control group. Besides these no adverse effect was found in both the groups.

\section{Limitation of the study}

Small sample size. 


\section{Conclusion}

Present study shows that sharbate anjabar is found to have almost equal effect with tranexamic acid on all the parameters studied but sample size was small so study on large sample size is needed before keeping it as an alternative for menorrhagia.

\section{References}

1. https://www.york.ac.uk/media/crd/ehc19.pdf

2. Asgari Z, Hoseinzadeh F, Hoseinzadeh A, Hafizi L (2014) Evaluation of the success rate of Endometrial Ablation by Cavaterm ${ }^{\text {tw }}$ plus technique. J Minim Invasive Surg Sci. 3: e12431.

3. Jurjani I (1903) Tarjuma Zakheerae Khawarzum Shahi, Vol 6. Munsh Nawal Kishore, Lucknow, pp. 590-597.

4. Sina I (2007) Al-Qanoon Fit-Tib. Idarae Kitabus Shifa, New Dehli, pp 1089-1091, 1065.

5. Borgatta L (2009) Heavy menstrual bleeding assessing impact, evaluating management options. Boston University.

6. Goshtasebi A, Mazari Z, Gandevani SB, Naseri M (2015) Antihemorrhagic activity of Punica granatum L. flower (Persian Golnar) against heavy menstrual bleeding of endometrial origin: a double-blind, randomized controlled trial. Med J Islam Repub Iran 29: 199.

7. Rushd I (1987) Kitabul Kulliyat. 2nd edn. CCRUM, New Delhi. pp. 114-117.

8. Majoosi ABA. Kamilus Sana. Idarae Kitab-us-Shifa, New Delhi, pp. 784,785 .

9. Kabeeruddin M. Makhzanul Mufradat. Ejaz Publication House, New Delhi, pp. 82, 96, 396.

10. Hakeem MAH (2002) Bustanul Mufradat. Idarae Kitab-ul-Shifa, New Delhi, pp. 75, 82, 96, 396.

11. Said HM (1997) Hamdard pharmacopeia of eastern medicine. Sri Satya Guru Publications, New Delhi, pp. 173, 353.
12. Jilani G (1995) Mukhzinul murakkabat. Ejaz Publishing House, New Delhi, pp. 198

13. Khan S (2006) Bayaze Khas al Maruful Ilaj. Ejaz Publishing House, New Delhi, pp. 269.

14. Jaisamrarn U, Srinil S (2005) Treatment of idiopathic menorrhagia with tranexamic acid. J Med Assoc Thai 88: 1-6.

15. Lee JY, Hahn PM, Van JP, Reid RL (2007) Treatment of menorrhagia with Tranaxaemic acid. J Obstet Gynaecol Can 22: 1-5.

16. Jeelani G (1996) Makhzanul Hikmat. Vol.II. Ejaz Publishing House, New Delhi, pp. 793-797.

17. Arzani A (1903) Tibbe Akbar. Faisal Publication, Deoband, pp. 594-597.

18. Dutta DC (2005) Textbook of gynecology. New Central Book Agency, Kolkata, pp.74, 175, 270, 355, 421, 431.

19. Arunkumara KKIU, Walpola BC, Subasingh S, Yoon MH (2011) Pterocarpus santalinus Linn. (Rath hadum) A review of its botany, uses, phytochemistry and pharmacology. JKSABC 54: 495-500.

20. Raaof AW, Al-Naqqash ZA, Jawad ALM, Muhsan SM (2013) Evaluation of the Activity of Crude Alkaloids Extracts of Zingiber officinale Roscoe., Thymus vulgaris L. and Acacia arabica L. as Coagulant Agent in Lab Mice. Biomed Biotechnol 1: 11-16.

21. Bhatnagar M, Parwani L, Sharma V, Ganguli J, Bhatnagar A (2013) Hemostatic, antibacterial biopolymers from Acacia arabica (Lam.) Willd. And Moringa oleifera (Lam.) as potential wound dressing materials. Indian J Exp Biol 51: 804-810.

22. Pattison H, Danniels J, Kai J, Gupta JK (2011) The measurement properties of the menorrhagia multi attribute quality of life scale: A pscycometric analysis. BJOG 1528-1531.

23. Marjoribanks J, Lethaby A, Farquhar C (2010) Surgery verses medical therapy for heavy menstrual bleeding, Newzealand. The Cochrane Collaboration, pp. 2-18. 